PRODUCTION

ENGINEERING

ARCHIVES
2016, Vol. 10, No 1, pp 25-28

ISSN 2353-5156

ISSN 2353-7779 (print version)

(online version)

Article history: Received: 02.02.2016

\title{
Automotive standard ISO/TS 16949 as a quality determinant
}

\author{
Joanna Rosak-Szyrocka ${ }^{1}$ \\ ${ }^{1}$ Institute of Production Engineering, Czestochowa University of Technology, Poland, asros@op.pl
}

\begin{abstract}
The main aim of this paper is to present the standard ISO/TS 16949. In the modern world of competition, quality is one of the most important factors. Modern organizations should gamble on quality, regardless of the type of business, because it is the basic form of running a business effectively. It is not only a factor of market success, but also an indication of organizational culture.
\end{abstract}

Key words - quality, automotive industry, ISO/TS 16949

\section{Automotive industry}

Thanks to the constant globalisation process and the systematically encountered fierce competition in international markets, change in the location of production processes has become a common practice for entrepreneurs representing the automotive sector all over the world. At the same time, the phenomenon of capital concentration can be observed in the automotive sector (CAlador D., Silvam B., Silvaboasorteoliveira A., SPAGNOLG S., SARANTOPOULOS A., LIL M. 2014).

The nature of the automotive industry in the era of accelerating technological progress, increasing consumer awareness and the ever changing market demands that global car-makers and their suppliers use and implement systems that are capable of providing the highest quality and safety of their products (BORKOWSKI S., ROSAKSZYROCKA J. 2009, ROBAK B.,ULEWICZ R. 2013, RoszaK M., SPilKa M., Kania A. 2015, RoszaK M. 2014). Apart from the individual automotive quality management systems characteristic to particular car- companies, the basic standard currently used in the international automotive markets is the quality management system based on the ISO/TS 16949 technical specification.

\section{ISO/TS 16949 standard}

ISO/TS 16949 together with ISO 9001(BORKOWSKI S., ULEWICZ R. 2000, BORKOWSKI S., ULEWICZ R. 2001) is posing guidelines for the implementation and maintenance of quality management systems in the whole chain of production processes and the production of spare parts in the automotive industry.

ISO/TS 16949 was developed by the International Automotive Task Force (IATF) to create common processes and procedures across the automotive industry. IATF members include some of the world's largest car manufacturers, including BMW Group, Chrysler Group and General Motors

(HTTP://WWW.KANTNERCOMPANY.COM/AA16949.KC.HTM.). 
"Revolutions" car manufacturers in quality management systems, causing difficulties in managing the factory system documentation, which was often carried out for several different independent quality management systems, such as working with Renault, BMW and Ford organization had to have three implemented quality management systems: EAQV(French quality management system), VDA 6.1(Germanquality management system), QS-9000 (U.S. quality management system).

The initiator of this project was the IATF (International Automotive Task Force- International Operations Team Industry Automotive) and national trade associations(AIAG -America, VDA - Germany,SMMT- United Kingdom,ANFIA-Italy, FIEV-France) who were responsible for the design of the technical group International Organization for Standardization ISO TS 176. As result of heated debates a new standard ISO/TS16949"Quality systems was set for suppliers to the automotive market- the specific assumptions for ISO9001:1994." The intention was to harmonize the requirements of the quality management systems of the automotive market: the U.S.(SQ9000), Italian (AYSOJ, French(EAQV) and German(VDA6.1)with ISO9001:1994. Message of ISO/TS16949:1994was to ensure continuous improvement, prevent defects, reduction of volatility and losses in the supply chain.

Top tips for implementing ISO/TS 16949 are following:

1. Make sure your whole business and supply chain are committed.

2. Engage your business and supply chain with good communication.

3. Compare existing quality management with ISO/TS 16949 requirements.

4. Get supply chain and stakeholder feedback on current quality processes.

5. Establish an implementation team to get the best results.

6. Map out and share roles, responsibilities and timescales.

7. Adapt the basic principles of the ISO/TS 16949 standard to your business.

8. Motivate staff and supply chain involvement with training.

9. Encourage your supply chain to become ISO/TS 16949 certified.
10. Regularly review your ISO/TS 16949 system to make sure it remains effective and that you are continually improving it.

According to the investors, the factors which make the automotive sector particularly attractive include:

- the convenient location of Poland in the centre of Europe and the proximity of approximately 40 large automotive industry plants:

- the developed network of sub-suppliers and cooperators which exceeds 900 plants of which over 500 companies hold ISO/TS 16949 quality certificates,

- the availability of a highly skilled labor force,

- an attractive system of investment incentives, including non-reimbursable grants and tax exemptions.

Poland is being increasingly chosen by investors operating in the automotive industry. Among approximately 40 automotive plants located in Central and Eastern Europe and operating in 16 are located in Poland (Table 1).

In 2014, 578.4 thousand passenger cars and commercial vehicles were produced, an increase of $0.6 \%$ against the previous year. Further increases in production is expected due to the commissioning of a plant manufacturing VW Crafter in Września in 2016 (maximum production capacity will amount to 100 thousand vehicles). Large production plants also operate in Tychy, Gliwice and in Wałbrzych. Toyota plants manufacture engines for themselves, Peugeot and Citroen; Fiat produces engines for their own needs and for Ford. The Volkswagen factory in Polkowice is a producer of engines for passenger cars and commercial vehicles for VW, as well as for Audi, Seat and Skoda. The Toyota Motor Manufacturing Poland in Wałbrzych manufacture engines and gearboxes for itself, Citroen and Peugeot. Also, General Motors' decision to launch production of the latest generation of Opel Astra is another significant investment. The production in the Gliwice plant commenced in September 2015. The investment outlays related to the implementation of the project amounted to approximately EUR 150 million(WWW.PAIZ.GOV.PL, HTTP://WWW.STANDARDS.ORG/STANDARDS/LISTING/ISO_TS_ 16949) 
Table 1. Engines and cars producers in Poland

\begin{tabular}{|c|c|}
\hline Localization area of the company & Name and kind of the company \\
\hline Słupsk & SCANIA (coaches) \\
& KAPENA (coaches) \\
\hline Poznań & VW Poznań (cars) \\
& Solaris (coaches) \\
& Solbus (coaches) \\
\hline Wrocław & WolkswagenWrześnia (cars factory from 2016) \\
\hline Katowice & Wałbrzych Toyota (engines) \\
\hline Kraków & JelczLaskowice Toyota (engines) \\
& Polkowice VW (engines) \\
& General Motors MP Tychy Engines factory (from 2017) \\
& Bielsko-Biała FPT Diesel/Gasoline (engines) \\
& AndrychówAndoria (engines) \\
& Tychy Fiat/Ford (cars) \\
& Gliwice GM Opel (cars) \\
& Tychy GM MP (engines) \\
\hline
\end{tabular}

Source own study basis on: www.paiz.gov.pldostęp: 23.04.2016

\section{Meaning ISO/TS 16949 in the company}

The benefits of being certified to ISO/TS 16949

Standard includes are but not limited to:

- Quality improvement in product \& process,

- Additional confidence to the customers,

- Common approach for managing Quality Management System,

- Reassignment of resources to quality improvement and

- Reduction in the multiple 3rd party registrations.

Implementation of ISO/TS 16949 management system is by no means an easy task. Organizations that have chosen the DIY (Do-It-Yourself) approach may find it confusing when upgrading their ISO 9001 management system to ISO/TS 16949 which includes additional automotive industry requirements and customerspecific requirements. For a company of around 100 staff, it will probably take close to a year to ready itself for the certification process. Even though ISO 9001 is not a pre-requisite for ISO/TS 16949, it is recommended to be implemented first.To be effective, a project team that consists of a team leaders and members from the key processes should be formed to spearhead for the project. Usually, in the initial phase, the team will spend almost $50 \%$ of their working time devoted to this purpose. Additional costs could come from the additional staff employed to temporarily take over the duties of the team members assigned.The costs of certification for ISO/TS 16949 depend on the scope of certification, size of the organization, number of manufacturing sites and remote locations. IATF through its "Rules for Achieving Recognition" states the audit man-day requirement be based on the number of employees in the organization. Most of the certification bodies follow the rule quite closely in quoting audit man-days for the organization. Certification bodies usually charge a certain day rate for the audit performed and the rate can be quite different among different countries and different certification bodies(Bevilacqua M., Ciarapica F.E., Giacchetta G., MARCHETTI B. 2011, CALADOR D.,SILVAM B., SILVABOASORTEOLIVEIRA A., SPAGNOLG S., SARANTOPOULOS A., LIL M. 2014).

\section{Summary and conclusions}

Requirement for the production of the product with the highest standards of quality beyond the use of the most modern technological methods is the implementation of quality management systems and their continuous improvement in organizations using qualitative methods. 
In Poland, the first quality systems began to be implemented in the 90's. The first companies that have decided to change the approach to quality have been exporting companies their products to EU countries. Boards of these companies wanted above all to enter new markets. So it was the main, and often only goal. However, after a few years, a large group of companies began to implement quality systems in accordance with ISO9000 with a view to acting in the Polish market. Their goals were similar to those of the leading European companies: reduce costs, increase competitiveness and internal benefits. Soon, however, entrepreneurs looking for a shorter route through the purchase documentation or even purchase a certificate became common. These, however, are not enough, most of the management decided to implement the system consciously aware of the benefits to be gained.At the end of June 2010, a total of 42,189 certificates were issued to ISO/TS 16949(ŁYSAK D. 2013). Asia Pacific region accounted for the biggest number of certificates issued - 16,585 (47\%). Among all the countries, China was the fastest growing country which itself accounted for 13,031 (31\%) certificates.

The fact that a given company has a certificate being in accordance with ISO/TS16949 is an important argument in business talks. This standard introduces a common ground for all participants of the supply chain(HYs K. 2015.).

\section{Literature}

1. BORKOWSKI S., ROSAK-SZYROCKA J. 2009. Procedury uzyskiwania znaków jakości, Wydawnictwo Politechniki Częstochowskiej, Częstochowa.

2. Borkowski S., Rosak-Szyrocka J.: Jakość usług medycznych w Polsce. Wydawnictwo PTM Warszawa 2010.

3. BORKOWSKI S., UlEWICZ R. 2000. The application of analytical methods in solving quality issues and quality improvement in the automotive industry, Advanced Manufacturing and Repair Technologies in Vehicle Industry.17th International Colloquium.ZielonaGóra-Łagów.

4. BORKOWSKI S., UlEWICZ R. 2001. The Quality System According to the Norm QS-9000,MT'01.The Third International Conference. Mechanical Engineering Technologies. Sofia.
5. http://www.kantnercompany.com/aa16949.kc.htm.

6. http://www.standards.org/standards/listing/iso ts 1 6949.

7. HYS K. 2015. ISO/TS 16949 analysis of the current trends. ZarządzanieiFinanse Journal of Management and Finance Vol. 13, No. 2/2015.

8. ŁYSAK D. 2013. Specyfikacja techniczna ISO/TS 16949, Problemy Jakości 10.

9. ROBAK B.,UleWICZ R. 2013. Use of selected instruments to solve quality problems in the automotive industry. Chapter 16. Product Quality Improvement and Companies' Competitiveness. Monography. Editing and Scientific Elaboration StanisławBorkowski, Manuela Ingaldi, Faculty of Logistics, University of Maribor, Celje.

10.ROSAK-SZYROCKA J. 2015.Systemy jakości waspekcie jakości ustug medycznych szpitali w Polsce. ABC Jakości, 3/2015.

11.ROSAK-SZYROCKA J., BORKOWSKI S. 2012.Procedure for Implementation Systems of Quality Management in Hospital [in:] ResearchMethodsImprovement, Borkowski S., Jasiński J. Yurii V. Makovetsky (eds.):, Dnipropetrovsk 2012.

12.ROSZAKM., $\quad$ SPILKAM., KANIAA. 2015.Environmentalfailuremode and effectsanalysis (FMEA)-a newapproach to methodology. HrvatskoMetalurskoDruštvo (HMD). Metalurgija. T. 54, Wyd 2, p. 449-451, 2015.

13.ROSZAKM.T. 2014.The synergy of the interaction of methods and tools of management on the technologies of materialprocesses. Archives of Materials Science. T. 82, p. 82.

14.WWW.PAIZ.GOV.PL.

15.Bevilacqua M., CiaraPiCa F.E., GiacchetTa G., MARCHETTI B. 2011.Implementation of a quality procedure based on Delphi method and the ISO/TS 16949: 2009 in the production ofstainlesssteeltubes forautomotiveexhaust systems, "International JournalofQuality\&ReliabilityManagement", Vol. 28, No. 8.

16.CALADORD.,SILVAMB.,SILVABOASORTEOLIVEIRA A.,SPAGNOLGS.,SARANTOPOULOSA., LIL M. 2014. Defining quality and maturity level applying the grey system and the method for automotive enterprises diagnosis, AmericanJournalof Theoretical and Applied Statistics,Vol.3,No.6-1. 